\title{
A Virtual Reality Prototype for Learning Maize Planting
}

\author{
Shakirat Oluwatosin Haroon \\ School of Computing, \\ Universiti Utara Malaysia, 06010 Sintok, \\ Kedah, Malaysia
}

\author{
Tosho Abdulrauf \\ School of Multimedia, \\ Universiti Utara Malaysia, 06010 Sintok, \\ Kedah, Malaysia
}

\begin{abstract}
Nowadays, the interest in Virtual Reality (VR) is growing from both the academia and other areas like in the industry. VR technology has been used widely as a major technological advance which can offer a significant support to education. The agricultural students at the University of Ilorin, Nigeria faces some challenges like lack of resources to enable them carry out their farming activities as expected due to a little or no sufficient farmland. Therefore, this research has been used to improve the students' education by developing a prototype for learning maize planting. The VR on maize planting has potentially helped the student in learning the maize planting process and also provide them with a new experience on exploring the virtual world. This study adopted the stratified sampling using 50 students in the agriculture department at the University of Ilorin and as a result, it was found that the use of the VR maize planting has a significant effect on the assessment of the students.
\end{abstract}

\section{Keywords}

Virtual Reality (VR), Learning, Maize, Planting

\section{INTRODUCTION}

The advent and advantages of multimedia technology, has greatly improved the educational system. Nowadays, computers have been applied to the learning process in a lot of ways, and this has really helped to monitor the progress, improvement and dissemination of information to the students as they progress [6]. There are various technologies that are being used for learning, some which include e-learning, webinars, virtual learning (VR). The Virtual Learning Environments (VLEs) utilizes the Virtual Reality (VR) as one of the components of e-learning, which is one of the latest and widely used multimedia elements now; it has been seen as an important application tool which can provide significant support for education [21].

Virtual Reality (VR) is an educational tool used to provide a simulated information environment and improve student learning. VR consists of many features which makes it a unique environment, some of these features is its sense of interactivity [14]. In addition, the VR learning environment is intuitive, experiential and interactive. It provides hands-on experience, simulations and visualization to both students and lecturers [2].

\section{PROBLEM STATEMENT}

Virtual Reality (VR) has been applied mainly in a lot of fields due to its cost-effectiveness solutions to problems. In various researches, it has been applied as an educational tool in various fields of study which are considered risky and costly, like; in medicine, aviation, imaging, entertainment, education, ecommerce and lots more and has also been made use of in secondary and primary classrooms [16]; [13]. But little attention has been given to the aspect of VR application in agriculture (farming).

Almost every tertiary institution situated in the urban environment lacks sufficient farmland to carry out their farming activities. In the case of University of Ilorin, some of the challenges faced by the agricultural science students include; little or no chance for them to go to the farmland, and most of the student does not participate in the actual involvement on the farmland to carry out the farming activities. The school has a little farmland which is not sufficient for the number of students and also lacks some essential resources. Other methods such as planting on the rooftop of a building and hydroponics would have been suggested, but due to some drawbacks like: cost of labor costs, expenses on fertilizer, the risk of infecting pathogens [12]; and the most of all is that they do not require any form of learning process. With all this, the use of VR as a learning tool is proposed. Therefore, this project work improve the practical learning of the agricultural students; by determining the appropriate elements of VR for the agriculture course content; precisely on maize plantation in a virtual world and to evaluate the proposed elements in terms of applicability through prototyping.

\section{RESEARCH QUESTIONS}

- How can the course content (agriculture science) be complemented using Virtual Reality?

- How can agricultural planting be carried out using Virtual Reality?

\section{RESEARCH OBJECTIVE}

- To determine the appropriate elements of VR to develop module for maize planting.

- To design and develop the prototype for maize planting

- To evaluate the usability of VR.

\section{TECHNOLOGY AND LEARNING}

Learning is the process of acquiring knowledge through proper medium and some set of processes [4]. Nowadays, learning is closely related to technology. Learning encompasses some essential components, which include; self-efficacy, learning skills development, student readiness in learning with others and a lot of strategies [20].

\subsection{Virtual Reality in Learning}

VR has been applied in many areas of learning. In a report, [11] uses virtual reality as a medical simulator (robot) to allow surgeons to carry out operations by practicing and seeing the outcome before a patient undergoes the real surgery. According to [1]; the researchers used virtual reality to design a Virtual Chemical Reaction Module (Vicher), which is an educational application that improves the engineering student chemical reaction by providing an educational environment that allows 
the students to explore what they have learned in the virtual world. VR has also been used to immerse architectural students in a virtual construction project, which allows the students to gain experience and develop a construction plan in a virtual environment [15]. More so, it has been used as a technology to improve the learning process in neurosurgical education by developing an interactive stereoscopic virtual reality (ISVR) in order to create a 3D experience of neurosurgical approaches [11].

\subsection{Elements of Virtual Reality Application}

In designing the VR prototype for maize planting, there are some essential multimedia elements that are required in order to make it simulative, educative and entertaining. They will be explained in the Table 1 [15]; [8].

\section{Table 1: Multimedia Elements}

\begin{tabular}{ll}
\hline $\begin{array}{c}\text { Multimedia } \\
\text { Elements }\end{array}$ & \multicolumn{1}{c}{ Explanation } \\
\hline Visual & $\begin{array}{l}\text { This is made up of: images, graphics, } \\
\text { real object, simulations, texts and } \\
\text { animations }\end{array}$ \\
\hline Images & $\begin{array}{l}\text { These consist of photos. They are } \\
\text { needed in certain areas of the design }\end{array}$ \\
\hline Graphics & $\begin{array}{l}\text { This represents the graphical designs } \\
\text { usually made up with special } \\
\text { characteristics }\end{array}$ \\
\hline Real objects & $\begin{array}{l}\text { These are the object of real life that } \\
\text { will be needed to add life to the } \\
\text { classroom. Objects such as; computer } \\
\text { and projector }\end{array}$ \\
\hline
\end{tabular}

\begin{tabular}{ll}
\hline Simulations & $\begin{array}{l}\text { This is the imitation of the real-life } \\
\text { situation. It will allow users to } \\
\text { interact with the virtual world, by } \\
\text { allowing them (users/students) to } \\
\text { view unreal objects in a virtual } \\
\text { environment }\end{array}$ \\
\hline Animations & $\begin{array}{l}\text { This is one main component in } \\
\text { multimedia elements. It involves the } \\
\text { understanding of some complex and } \\
\text { abstract idea. }\end{array}$ \\
\hline Audio & $\begin{array}{l}\text { This is made up of the audio effects } \\
\text { used in the design, such as the } \\
\text { narration }\end{array}$ \\
\hline
\end{tabular}

\subsection{Multimedia Learning Theory}

There are various learning theories in the educational environment, but the multimedia theory is chosen in this research work because of its simultaneous use of different forms of media, including images, text, sound and animations. Based on the work carried out by [9], a framework was presented called Cognitive Theory of Multimedia Learning. The framework will be used in the design of this prototype.

The cognitive theory of multimedia learning focuses on both the auditory and visual channel. The theory is important in education, in order to improve multimedia design [9]. The framework of Cognitive Theory of Multimedia Learning is as shown in Figure 1.

The framework of the cognitive theory of multimedia learning above depicts five cognitive processes; these processes are likely to appear many times in the multimedia presentation. They are explained in the Table 2 [10].

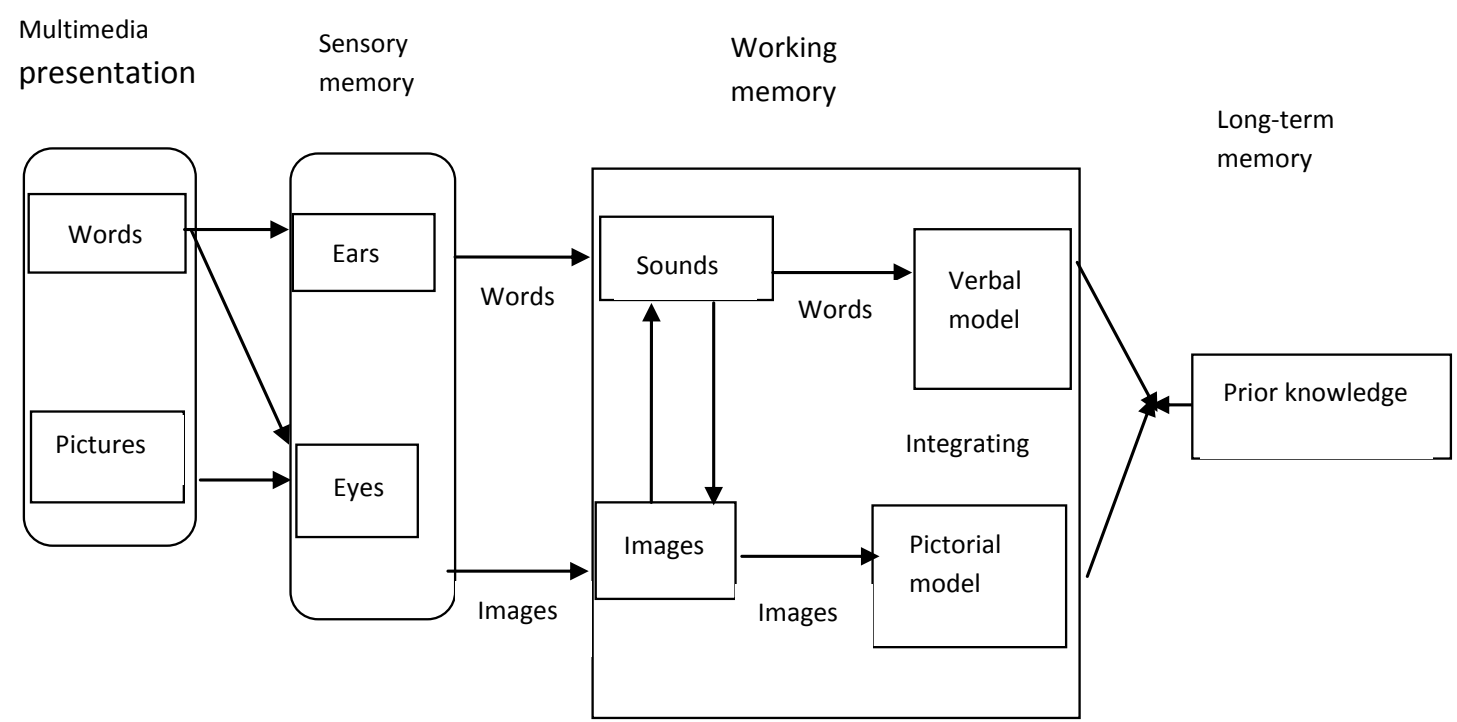

Figure1: Framework for Cognitive Theory of Multimedia Learning 
Table 2: The Five Cognitive Processes Involved in the Cognitive Theory of Multimedia Learning

\begin{tabular}{ll}
\hline Process & Description \\
\hline Selecting words & $\begin{array}{l}\text { This triggers relevant words } \\
\text { in the working memory of } \\
\text { the multimedia presentation } \\
\text { to create sounds }\end{array}$ \\
\hline Selecting images & $\begin{array}{l}\text { This triggers relevant } \\
\text { pictures in the working } \\
\text { memory of the multimedia } \\
\text { presentation to create } \\
\text { images }\end{array}$ \\
\hline Organizing words & $\begin{array}{l}\text { This allows to create a } \\
\text { coherent verbal model in } \\
\text { the working memory } \\
\text { among selected words }\end{array}$ \\
\hline Organizing images & $\begin{array}{l}\text { This allows to create a } \\
\text { coherent pictorial model in } \\
\text { the working memory } \\
\text { among selected images }\end{array}$ \\
\hline Integrating & $\begin{array}{l}\text { This is the connection } \\
\text { involve between the verbal, } \\
\text { pictorial models and the } \\
\text { prior knowledge. }\end{array}$ \\
\hline
\end{tabular}

\section{DEVELOPMENT OF PROTOTYPE}

This is the phase where the research questions were answered, a VR prototype for learning maize planting was designed. Autodesk Maya was used in the designing and audio was also imported into it. Based on the cognitive theory of multimedia learning, the prototype consists of images and audio. This is as shown in Figures 2,3 \& 4.

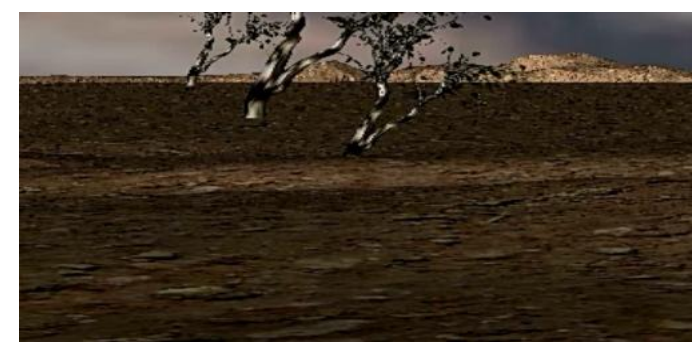

Figure 2: Screen shot of the farmland in the maize planting prototype

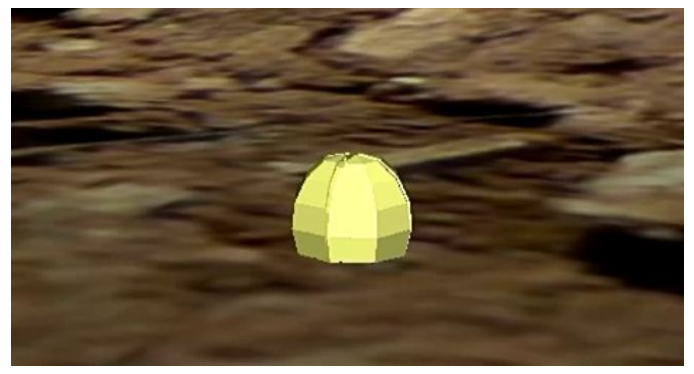

Figure 3: Screen shot of the seedling stage in the maize planting prototype

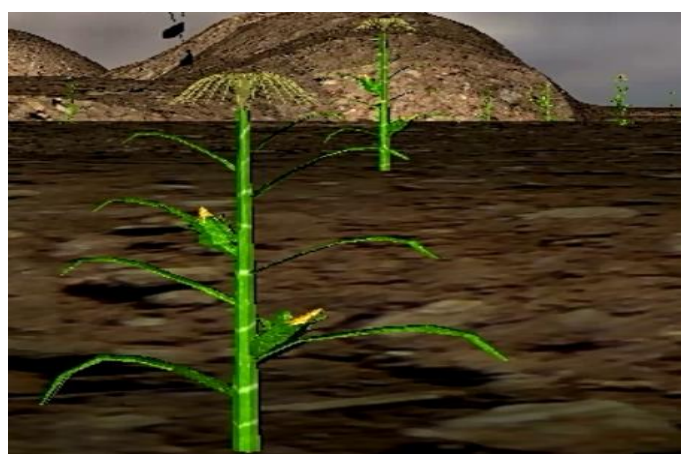

Figure 4: Screen shot of the maize germination stage

\section{METHODOLOGY OF THE STUDY}

The general Methodology adopted from [19] was used in this research work. The phases included in the methodology are; Awareness of problem, suggestion, development, evaluation and conclusion.

In this study, the Likert type scale was used and the questionnaire was handed out to 50 students, who are studying at the agriculture department at the University of Ilorin; while 31 of them returned it. The agriculture students were chosen because the prototype will be used by them. The questionnaire was grouped into four parts, in the first part there were demography questions. In the second part, questions were asked about the user experience with computer, the third question was based on their experience with VR and the fourth part was on their experience with using the simulated VR. The questionnaire was sent to the student together with the prototype packaged in a CD-ROM, after which it was shared with the student by a representative. The questionnaire was distributed to the student by hand, then the first three components (demographic variable, experience with computer and experience with VR) of the questionnaire were answered by them before they make use of the prototype; then after answering that, they make use of the prototype and then answered the last part of the questionnaire, which is on their experience with the use of the prototype.

The questions were adopted from various questionnaires conducted by other researchers [3]; [15]. In order to analyze the data, SPSS (Statistical Package for Social Sciences) was used and the descriptive statistics analyzed.

\subsection{Descriptive Analysis}

In the questionnaire component of user experience with the prototype, some selected questions from the questionnaire were chosen so as to know the user's perception after using the prototype. Table 3 shows the descriptive analysis formed from some questions in the questionnaire; stating the mean and standard deviation of each item. While Figures 5, 6, 7, 8 and 9 display the bar chart of respondents. 
Table 3: Descriptive Statistics

\begin{tabular}{|c|c|c|c|}
\hline Items & $\mathrm{N}$ & Mean & $\begin{array}{c}\text { Std. } \\
\text { Deviation }\end{array}$ \\
\hline $\begin{array}{l}\text { 1. Learning through the } \\
\text { maize VR enhance } \\
\text { my } \\
\text { efficiency }\end{array}$ & 31 & 4.2258 & 66881 \\
\hline $\begin{array}{l}\text { 2. Learning through the } \\
\text { maize VR improve } \\
\text { my remembering skill }\end{array}$ & 31 & 4.0000 & .57735 \\
\hline $\begin{array}{l}\text { 3. Learning through the } \\
\text { maize VR enhance } \\
\text { my } \\
\text { performance }\end{array}$ & 31 & 4.1613 & .68784 \\
\hline $\begin{array}{l}\text { 4. The maize VR } \\
\text { environment provides } \\
\text { a complete learning } \\
\text { information }\end{array}$ & 31 & 3.9032 & .70023 \\
\hline $\begin{array}{l}\text { The maize VR } \\
\text { environment provides } \\
\text { information that is } \\
\text { easy to comprehend }\end{array}$ & 31 & 4.2581 & .68155 \\
\hline
\end{tabular}

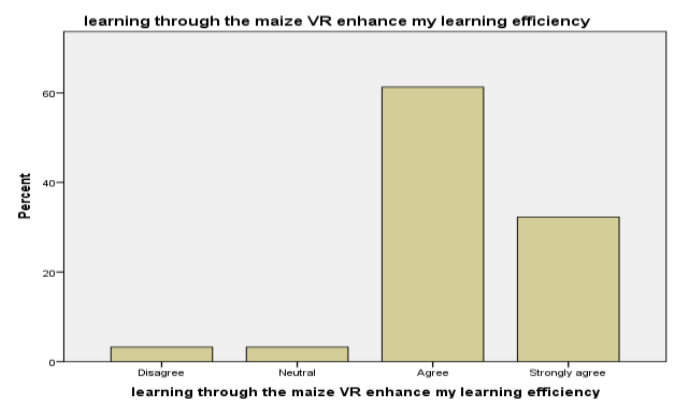

Figure 5: Learning through the maize VR enhanced my learning efficiency

In the respondent's experience with VR, $61.3 \%$ of the respondents agreed that the prototype enhanced their learning efficiency.

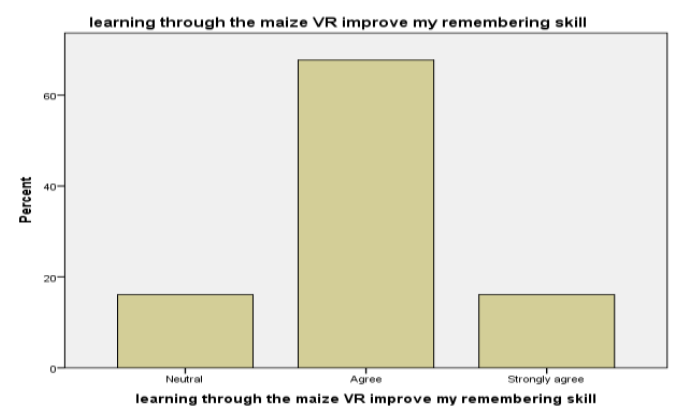

Figure 6: Learning through the maize VR improved my remembering skill

Figure 6 shows that $67.7 \%$ of the respondents agreed that the prototype improved their remembering skill.

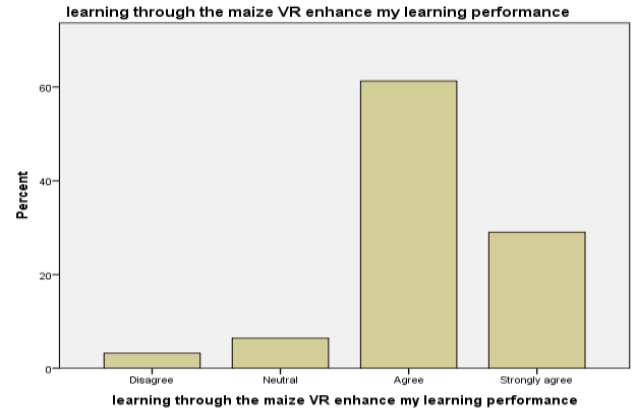

Figure 7: Learning through the maize VR enhanced my learning performance

Figures 7 and 8 respectively, illustrates that $61.3 \%$ of the respondents agreed that the prototype enhanced their learning performance and provided a complete learning information for them.

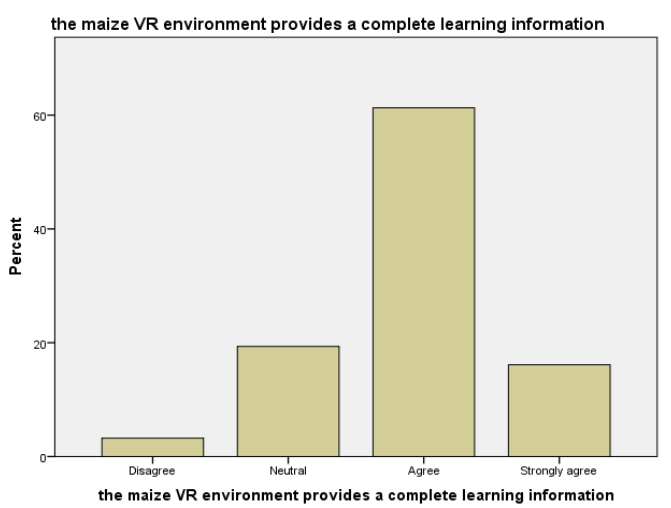

Figure 8: Learning through the maize VR provided a complete learning information

And then finally, figure 9 shows that $48.4 \%$ of the respondents agreed that the information on the prototype was easy to comprehend.

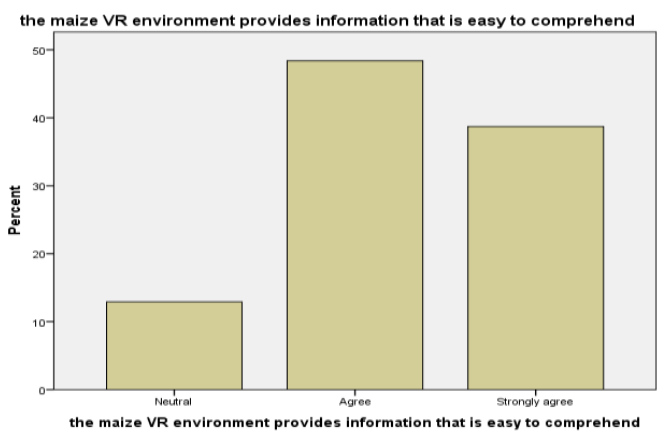

Figure 9: Learning through the maize VR provided information that was easy to comprehend

\subsection{Findings}

The result of the findings from the analysis also shows that the VR application has a prospective future that can assist in learning. From all the results above, it was concluded that the use of the VR maize planting prototype greatly affects the assessment of the students (the respondents); by providing a new experience into the students learning style and also helped them to learn maize planting practices. This study is inline with the usability of multimedia elements to serves as learning strategies [18]. 


\subsubsection{Implication of the Study}

This can be explained as how this study or research work can be used, its contribution, and effects for students and the academics as a whole.

\subsubsection{Implication to Students}

- This research work can be used by to assist students to learn about maize planting

- It can allow them to experience and practice the maize planting procedures

This research work can enhance the student's learning process with VR technology.

\subsubsection{Implication to Academics, Educators or Lecturers}

- The VR technology can be used by the educators or lecturers to teach the maize planting practical and other agricultural practical courses in schools.

- It can be implemented or applied to other fields of study; not only in the Agric, most especially the practical based courses. For example, Geography.

\section{DISCUSSION AND CONCLUSION}

The aim of this research work was to design a prototype that will assist students in learning maize planting, and this was achieved by designing a Virtual Reality maize planting prototype to assist the students in their learning process.

In conclusion, this study designed a Virtual Reality prototype for learning maize planting that can assist the students in learning maize planting practices. According to the survey result, it was found that the use of the VR maize planting has enhanced the student learning process and provided them with a new learning style in learning maize planting.

Therefore, it is concluded that there is a positive effect on the usage of the VR prototype in regards to the user's learning.

\section{REFERENCES}

[1] Bell, J. T., \& Fogler, H. S. (2004). The Application of Virtual Reality To Chemical Engineering Education. VR, 4, 217-218

[2] Bricken, M. (1991). Virtual Reality Learning Environments: potentials and challenges. ACM SIGGRAPH Computer Graphics, 25(3), 178-184.

[3] Bricken, M., \& Byrne, C. M. (1992). Summer Students in Virtual Reality: A Pilot Study on Educational Applications of Virtual Reality Technology

[4] Caffarella, R., \& Merriam, S. B. (2000). Linking the Individual Learner to the Context of Adult Learning. Handbook of adult and continuing education, $55-70$.

[5] Chapman, N., \& Chapman, J. (2008). Digital media tools. John Wiley \& Sons.
[6] Elzinga, C. B., \& Parry, K. (2000). "Technology Assisted Learning”. U.S. Patent No. 6,077,085. Washington, DC: U.S. Patent and Trademark Office.

[7] Fogler, H. S. (2004). The Application of Virtual Reality to Chemical Engineering Education. VR, 4, 217-218

[8] Kuniavsky, M. (2010). Smart Things: Ubiquitous Computing User Experience Design: Ubiquitous Computing User Experience Design. Elsevier.

[9] Mayer, R. E. (2005). Cognitive Theory of Multimedia Learning. The Cambridge handbook of multimedia learning, 31-48.

[10] Mayer, R. E., \& Alexander, P. A. (Eds.). (2011). Handbook of research on learning and instruction. New York, NY: Routledge.

[11] McCloy, R., and Stone, R. (2001). Science, medicine, and the future: Virtual reality in surgery. BMJ: British Medical Journal, 323(7318), 912.

[12] Rolot, J. L., \& Seutin, H. (1999). Soilless Production of Potato Minitubers Using a Hydroponic Technique. Potato Research, 42(3-4), 457-469.

[13] Santana-Fernández, J., Gómez-Gil, J., and del-Pozo-SanCirilo, L. (2010). Design and Implementation of a GPs Guidance System for Agricultural Tractors Using Augmented Reality Technology. Sensors, 10(11), 1043510447

[14] Sherman, W. R., \& Craig, A. B. (2002). Understanding Virtual Reality: Interface, application, and design. Elsevier.

[15] Smith, S., Taylor, K., Green, T., Peterson, N., Garrety, C., Kemis, M., and Thompson, A. (2009). Using Virtual Reality Tools in Design and Technical Graphics Curricula: An experience in learning. Engineering Design Graphics Journal, 69(1).

[16] Strangman, N., and Hall, T. (2003). Virtual Reality/Simulations. Wakefield, MA: National Center on Accessing the General Curriculum.

[17] Tidrick, B. (2008). Virtual interactive courtroom environments are here will your agency be ready?

[18] Tosho, A., Abdul Mutalib, A., \& Nur Abdul Salam, S. (2014). Usability of Instructional Interface: Accessibility Strategies of Courseware Design for Distance Learning, Nigeria. International Journal of Computer Applications,106(18), 32-36.

[19] Vaishnavi, V., and Kuechler, W. (2004). Design research in information systems.

[20] Watkins, C. (2001). Learning about learning enhances performance.

[21] Youngblut, C. (1998). Educational Uses of Virtual Reality Technology Institute for defense analyses Alexandria VA. 